\section{Herbicide Application Timings on Weed Control and Jack-0-Lantern Pumpkin Yield}

\author{
S. Alan Walters ${ }^{1}$ and Bryan G. Young
}

AdDitional INDEX wORDs. clethodim, clomazone, Cucurbita pepo, ethalfluralin, glyphosate, halosulfuron-methyl, paraquat, postemergence, preemergence, $s$-metolachlor, weed management

SUMMARY. A study was conducted in a no-tillage (NT) jack-o-lantern pumpkin (Cucurbita pepo) field following winter wheat (Triticum aestivum) harvest to determine the effects of using registered herbicides at various timings on weed control and pumpkin yield. All application timings used in this study were important to maximize weed control over the pumpkin growing season. For an initial stale seedbed burndown treatment, paraquat provided better broadleaf weed control than glyphosate, which lead to greater pumpkin yields. The use of $s$-metolachlor + halosulfuron-methyl preemergence (PRE) and clethodim postemergence (POST) gave the best results for the second series of herbicide applications which related to higher pumpkin yields compared with none or only a PRE application. The last application timing (midseason POST-directed paraquat application between rows) also improved weed control and provided higher pumpkin yields compared with no treatment. Growers who use a stale seedbed burndown treatment in NT pumpkin production, before seedling emergence or transplanting, will generally use glyphosate although this study indicated that paraquat may prove to be a better choice depending on the weed species that are present at this application timing. Most weed control in NT pumpkin production is achieved by a PRE application of various tank-mixed herbicides for both grass and broadleaf weed control, with a POST grass herbicide, a POST application of halosulfuron-methyl, or both [for control of nutsedge (Cyperus sp.), specific broadleaf weed species, or both] applied 3 to 4 weeks later, and this study indicated that the use of labeled PRE and POST herbicides are essential to optimize weed control and pumpkin yields in NT. Most pumpkin growers do not use a POSTdirected application of a nonselective herbicide (such as paraquat) before vines cover the soil surface although it appears that this application may be warranted to control weeds that have emerged later in the growing season to maximize pumpkin yield, especially if POST midseason over-the-top herbicide applications are not used. This study indicated that in addition to applying the limited PRE and POST herbicides available for weed control in pumpkin, the use of other chemical weed management practices (e.g., stale seedbed herbicide treatments or POST-directed nonselective herbicide applications) can provide valuable weed control in NT production systems and should be considered by growers to maximize pumpkin yield.

$\mathrm{T}$ he use of NT production practices for jack-o-lantern pumpkin is becoming more widely used in the eastern and midwestern United States (Morse et al., 2001; Rapp et al., 2004; Walters et al., 2008) although most are still produced using conventional tillage (CT). Pumpkin growers have an interest in NT production practices for many different reasons besides just decreasing the overall cost of production. NT practices provide an effective, cost-efficient means of reducing soil erosion, increasing soil organic matter, as well as improving water conservation and

Professor, Department of Plant, Soil, and Agricultural Systems, Southern Illinois University, Carbondale, IL 62901

${ }^{1}$ Corresponding author. E-mail: awalters@siu.edu. nutrient-holding capacities of soils (Blevins et al., 1983; Johnson and Hoyt, 1999). Furthermore, pumpkin fruit produced in NT tend to be cleaner with little to no soil on the fruit skin surface, resulting from pumpkins residing on cover crop or other crop residues, and these pumpkins often garner a premium price compared with those fruit grown in CT that often have soil attached to the fruit (Walters et al., 2008).

The wide-scale implementation of NT practices for pumpkin production has been limited primarily due to the lack of available herbicides to control problematic broadleaf weeds (Galloway and Weston, 1996; Rapp et al., 2004; Walters and Young, 2010; Walters et al., 2008). Chemical weed control is essential to obtain the highest possible pumpkin yields in NT production systems, and tank mixtures of various herbicides are generally necessary to maximize weed control (Brown and Masiunas, 2002; Kammler et al., 2008). Although weeds are a major problem in NT pumpkin production systems, there are limited numbers of registered herbicides available for weed control. The majority of herbicides registered for pumpkins are for preemergence applications and provide limited control of broadleaf weeds and nutsedge (Brown and Masiunas, 2002; Grey et al., 2000); since moisture is required for activation of these herbicides, most are ineffective when limited amounts of rainfall occur within $10 \mathrm{~d}$ of application. Although several PRE herbicides including clomazone + ethalfluralin, halosulfuron-methyl, and s-metolachlor will provide better weed control in NT compared with many older cucurbit herbicides, the use of effective postemergence herbicides for control of both grass and broadleaf weeds is important to achieve success in NT vegetable production systems. Grass weeds can be effectively controlled in most vegetable crops with

\begin{tabular}{lllc}
\hline $\begin{array}{l}\text { Units } \\
\begin{array}{l}\text { To convert U.S. to SI, } \\
\text { multiply by }\end{array}\end{array}$ & U.S. unit & SI unit & $\begin{array}{l}\text { To convert SI to U.S., } \\
\text { multiply by }\end{array}$ \\
\hline 0.4047 & $\mathrm{acre}(\mathrm{s})$ & $\mathrm{ha}$ & 2.4711 \\
0.0731 & $\mathrm{fl} \mathrm{oz} / \mathrm{acre}$ & $\mathrm{L} \cdot \mathrm{ha}^{-1}$ & 13.6840 \\
0.3048 & $\mathrm{ft}$ & $\mathrm{m}$ & 3.2808 \\
0.0929 & $\mathrm{ft}^{2}$ & $\mathrm{~m}^{2}$ & 10.7639 \\
9.3540 & $\mathrm{gal} / \mathrm{acre}$ & $\mathrm{L}^{2} \mathrm{ha}^{-1}$ & 0.1069 \\
2.54 & inch(es) & $\mathrm{cm}^{3}$ & 0.3937 \\
16.3871 & inch & $\mathrm{cm}^{3}$ & 0.0610 \\
0.4536 & $\mathrm{lb}$ & $\mathrm{kg}$ & 2.2046 \\
1.1209 & $\mathrm{lb} / \mathrm{acre}$ & $\mathrm{kg} \cdot \mathrm{ha}^{-1}$ & 0.8922 \\
70.0532 & $\mathrm{oz} / \mathrm{acre}$ & $\mathrm{g} \cdot \mathrm{ha}^{-1}$ & 0.0143 \\
6.8948 & $\mathrm{psi}$ & $\mathrm{kPa}$ & 0.1450 \\
1.1692 & $\mathrm{pt} / \mathrm{acre}$ & $\mathrm{L} \cdot \mathrm{ha}^{-1}$ & 0.8553
\end{tabular}


POST applications of clethodim or sethoxydim; however, there is a lack of effective herbicides that can be applied POST for broadleaf weed control in vegetable crops. The only POST herbicide labeled for broadleaf weed control that can be applied overthe-top of pumpkin foliage is halosulfuron-methyl. Halosulfuron-methyl can also be applied PRE in pumpkin for control of several different broadleaf weeds.

The use of other chemical weed management practices for NT pumpkins, such as stale seedbed herbicide treatments or POST-directed herbicide applications to row middles with nonselective herbicides before pumpkin plants vining, may provide viable weed control options. Johnson and Mullinix (1998) indicated that stale seedbed weed management is critical to maximize yields of crops that have limited herbicide options. Maynard (2008) indicated that weeds in NT pumpkins were adequately controlled by using the tank-mixed PRE herbicides (clomazone + ethalfluralin) followed by using a POST-directed shielded application of a nonselective, nonresidual herbicide (glyphosate) to row middles before pumpkin plant vining. Considering the lack of weed management options for NT vegetable crops such as pumpkins, these methods of chemical weed control may provide the additional weed control needed to maximize yields in this type of system. There are limited reports on the influence of NT and crop residue mulching practices in pumpkins, particularly when used in combination with chemical weed control (Walters and Young, 2010). Therefore, a study was conducted to evaluate the effectiveness of using registered herbicides at various timings for weed control in NT pumpkin production following winter wheat harvest.

\section{Materials and methods}

A field study was conducted at the Horticultural Research Center at Southern Illinois University in Carbondale during 2008 and 2009 to determine the effects of using registered herbicides at various timings on weed control and yield of jack-olantern pumpkin grown in a NT production system. The field soil was a Hosmer silt loam (fine-silty, mixed, mesic Typic Fragiudalfs; Herman,
1979). Winter wheat was drill planted on 20 Oct. each year (2007 and 2008) at 1.2 million seeds/acre, with wheat harvested in early June during the following spring.

The experiment was designed as a split-split plot treatment arrangement with four replications. The main plots were two stale seedbed POST burndown herbicide treatments applied $3 \mathrm{~d}$ before transplanting: 1) $22 \mathrm{floz} /$ acre glyphosate (Roundup WeatherMax; Monsanto, St Louis) and 2) 3 pt/acre paraquat (Gramoxone Inteon; Syngenta Crop Protection, Greensboro, $\mathrm{NC})+1 \% \mathrm{v} / \mathrm{v}$ crop oil concentrate (COC; Growmark, Bloomington, IL). The subplots consisted of: 1) $1.33 \mathrm{pt} /$ acre $s$-metalochlor (Dual Magnum; Syngenta Crop Protection) $+0.5 \mathrm{oz} / \mathrm{acre}$ halosulfuron-methyl (Sandea; Gowan, Yuma, AZ) - PRE; 2) s-metalochlor (1.33 pt/acre) + halosulfuron-methyl $(0.5 \mathrm{oz} /$ acre $)-\mathrm{PRE}$ then $8 \mathrm{fl} \mathrm{oz} /$ acre clethodim (SelectMax; Valent USA, Walnut Creek, CA) + 1\%v/v COC POST; and 3) no herbicide treatment. The PRE herbicides were applied to the soil at $\mathrm{l} \mathrm{d}$ before transplanting and the POST application of clethodim was made about $28 \mathrm{~d}$ after transplanting (DAT). The sub-subplots consisted of either paraquat + COC directed POST application between pumpkin rows using a plastic shielded sprayer at $\approx 50$ DAT or no treatment. All herbicide treatments were applied with a carbon dioxide-pressurized backpack sprayer using flat-fan spray tips (TeeJet XR 8003; Spraying Systems, Wheaton, IL) at 40 psi in 20 gal/acre water. Overhead irrigation was used to activate the preemergence herbicides and to provide at least 1 inch of water to plants per week throughout the growing season.

'Magic Lantern' pumpkin seed (Harris Moran Seed, Modesto, CA) were germinated in a greenhouse and grown in 72-cell plastic containers (each cell was 6.2 inch $^{3}$ volume) filled with a soilless media (2:1:1 peat: perlite:vermiculite ratio). Plants were hardened off in a cold frame 3 to $4 \mathrm{~d}$ before transplanting in the field. On 25 June each year, plants were transplanted into the field at the two- to three-leaf stage. Pumpkin transplants were planted into 40 - $\mathrm{ft}$-long plots that had a 5 - $\mathrm{ft}$ alley between plots. Center-to-center row spacings were $6 \mathrm{ft}$ with 4 -ft in-row spacings allowing 10 plants per plot.
Standard fertility and pesticide practices for pumpkin production in Illinois were followed (Egel et al., 2008, 2009). At transplanting, imidacloprid (Admire 2 Flowable; Bayer CropScience, Research Triangle Park, NC) was applied at $20 \mathrm{oz} /$ acre to provide insect control for the first 30 DAT. At 1 week after pumpkin transplanting, $65 \mathrm{lb} /$ acre nitrogen $(\mathrm{N}), 29$ $\mathrm{lb} /$ acre phosphorus $(\mathrm{P})$, and $54 \mathrm{lb} /$ acre potassium $(\mathrm{K})$ were broadcast applied, with the source of $\mathrm{N}$ from ammonium nitrate $\left(\mathrm{NH}_{4} \mathrm{NO}_{3}\right), \mathrm{P}$ from phosphorus pentoxide $\left(\mathrm{P}_{2} \mathrm{O}_{5}\right)$, and $\mathrm{K}$ from potassium oxide $\left(\mathrm{K}_{2} \mathrm{O}\right)$. Plants were side-dressed with $62 \mathrm{lb} /$ acre $\mathrm{N}$ at 5 weeks after transplanting, with the source of $\mathrm{N}$ from calcium nitrate $\left[\mathrm{Ca}\left(\mathrm{NO}_{3}\right)_{2}\right]$. Diseases and insects were controlled by spraying recommended rates of esfenvalerate (Asana XL; E.I. du Pont de Nemours, Wilmington, DE), chlorothalonil (Bravo WeatherStik; Zeneca, Wilmington, DE) or azoxystrobin (Quadris, Syngenta Crop Protection), and thiophanatemethyl (Topsin M; Cerexagri, King of Prussia, PA) every $10 \mathrm{~d}$ starting at the 10- to 12-leaf stage until first harvest. Once fruit set had begun, copper hydroxide $\left[\mathrm{Cu}(\mathrm{OH})_{2}\right]$ (Kocide, E.I. du Pont de Nemours) was also added into the tank mixture. A honeybee (Apis mellifera) hive was placed in the field at flowering each year within $15 \mathrm{~m}$ of the experimental site.

Both pumpkin plant growth reduction and weed control ratings were taken at $\approx 30$ and 60 DAT pumpkin, respectively. Pumpkin plant growth reduction (stunting from weed competition) was rated from $0 \%=$ no stunting to $100 \%=$ severe plant stunting with no new growth, with the $0 \%$ growth reduction reference provided by the two border rows that surrounded the experiment which were weeded by hand every 2 weeks. Grass and broadleaf weed control was rated from $0 \%=$ no weed control to $100 \%=$ complete weed control. The grass weeds present in the field included giant foxtail (Setaria faberi), large crabgrass (Digitaria sanguinalis), and johnsongrass (Sorghum halepense). Broadleaf weeds present included common purslane (Portulaca oleracea), smooth groundcherry (Physalis subglabrata), prostrate spurge (Euphorbia maculata), horseweed (Conyza canadensis), common ragweed (Ambrosia artemisiifolia), redroot pigweed 
(Amaranthus retroflexus), prickly sida (Sida spinosa), and various morning glory species (Ipomoea sp.). Horseweed was the only weed that had a consistent density in all plots; thus, the final density of this weed was rated in all experimental units. All other weeds were lumped into either grass or broadleaf for control and final density measurements. Percent soil coverage of wheat residues was rated from $0 \%$ (no residues) to $100 \%$ (soil completely covered with residues) at 10 random locations in the field. Weed densities from two random $0.5-\mathrm{m}^{2}$ areas in each plot were determined at the first fruit harvest $(\approx 80$ DAT). Number, weight (pounds), and diameter (inches) of mature, orangecolored pumpkins were determined at two harvests on $\approx 10$ Sept. and 10 Oct. each year.

Data were subjected to analysis of variance procedures using the general linear models procedure of SAS (version 9.2; SAS Institute, Cary, NC) appropriate for a split-split plot experimental design to determine the effectiveness of the initial burndown herbicide treatments, the PRE and/or POST herbicide treatments, and the midseason directed POST paraquat application on pumpkin plant growth reduction, weed control, weed density, and pumpkin yield. Crop growth reduction and weed control ratings were analyzed as percentages and as transformed (arcsine of the square root) percentages; since transformation did not change the analysis, actual means are presented. Data were pooled across years for analysis, and no interactions $(P>0.05)$ were observed between the main effects and year; thus, data were pooled over years. Furthermore, no interactions $(P \leq$ 0.05 ) were detected among the three main effect treatments. Fisher's protected least significant difference test was used to separate treatment differences at $P \leq 0.05$.

\section{Results}

The wheat crop residues left after harvest operations left significant organic mulch over the soil surface. For both growing seasons, wheat stubble and straw left from harvest operations provided about $70 \%$ to $75 \%$ soil coverage.

WeED CONTROL. Both early- and late-season grass and early-season broadleaf weed control did not differ $(P>0.05)$ between the two stale seedbed burndown herbicide treatments (Table 1). However, differences were detected $(P \leq 0.05)$ between these initial burndown treatments for late-season broadleaf weed control with paraquat providing greater control than glyphosate.

The second and final herbicide applications both influenced grass and broadleaf weed control. For the early-season timing, the PRE herbicide application provided greater $(P \leq$ 0.05 ) grass and broadleaf weed control than the no herbicide treatment (Table 1). Late-season grass control was improved with the addition of the POST clethodim application compared with only the PRE treatment, but the PRE application provided greater weed control than the no herbicide. There was no advantage for broadleaf weed control with the POST clethodim application, which was expected, and no differences $(P>$ 0.05 ) were observed between the three treatments evaluated for lateseason broadleaf weed control. The final midseason herbicide application, which consisted of paraquat between rows, provided significant improvement in both late-season grass and broadleaf weed control.

Table 1. Influence of herbicides and application timings in no-tillage pumpkin production on weed control, crop growth reduction, and weed population densities.

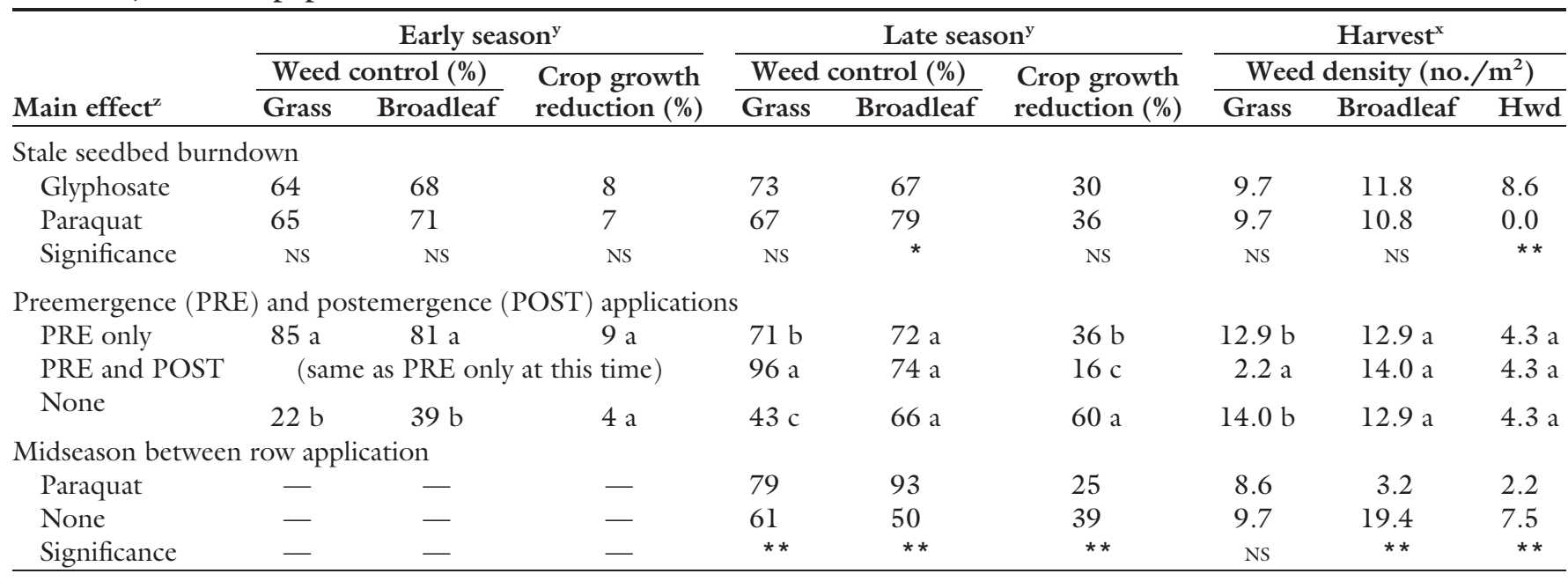

${ }^{2}$ The stale seedbed burndown treatments consisted of glyphosate $(22 \mathrm{fl} \mathrm{oz} /$ acre $)$ or paraquat ( $\left.3 \mathrm{pt} / \mathrm{acre}\right)+1 \% \mathrm{v} / \mathrm{v}$ crop oil concentrate (COC) applied $3 \mathrm{~d}$ before transplanting pumpkins. The preemergence (PRE) and postemergence (POST) applications were: 1$) \mathrm{PRE}$ only- $s$-metalochlor $(1.33 \mathrm{pt} / \mathrm{acre})+\mathrm{halosulfuron}-\mathrm{methyl}(0.5 \mathrm{oz} / \mathrm{acre}) ; 2) \mathrm{PRE}$ and POST-s-metalochlor $(1.33 \mathrm{pt} / \mathrm{acre})+$ halosulfuron-methyl $(0.5 \mathrm{oz} / \mathrm{acre})-\mathrm{PRE}$ and then clethodim $(8 \mathrm{fl} \mathrm{oz} / \mathrm{acre})+1 \% \mathrm{v} / \mathrm{v} \mathrm{COC}-\mathrm{POST}$; and 3$)$ no herbicide treatment. The PRE herbicides were applied to soil $1 \mathrm{~d}$ before transplanting and the POST application of clethodim was made 4 weeks after transplanting. The midseason between row application was paraquat $(3 \mathrm{pt} / \mathrm{acre})+1 \% \mathrm{v} / \mathrm{v}$ COC directed POST between pumpkin rows at $\approx 50 \mathrm{~d}$ after transplanting $(\mathrm{DAT})$ or no treatment; $1 \mathrm{fl}$ oz $/$ acre $=$ $0.0731 \mathrm{~L} \cdot \mathrm{ha} \mathrm{a}^{-1}, \mathrm{l} \mathrm{pt} / \mathrm{acre}=1.1692 \mathrm{~L} \cdot \mathrm{ha}^{-1}, \mathrm{l} \mathrm{oz} /$ acre $=70.0532 \mathrm{~g} \cdot \mathrm{ha}^{-1}$.

${ }^{y}$ Early- and late-season ratings for both pumpkin plant growth reduction and weed control were taken at $\approx 30$ and 60 DAT pumpkin, respectively. Early-season ratings were taken before first POST spray and before midseason between row paraquat application. The grass weeds present in the field included giant foxtail, large crabgrass, and johnsongrass, while broadleaf weeds present included common purslane, smooth groundcherry, prostrate spurge, horseweed, common ragweed, redroot pigweed, prickly sida, and various species of morning glory.

${ }^{x} \mathrm{Hwd}=$ horseweed. Weed densities based on two random $0.5-\mathrm{m}^{2}\left(5.38 \mathrm{ft}^{2}\right)$ areas in each plot that were taken at the first fruit harvest $(\approx 80 \mathrm{DAT}$ pumpkin $) ; 1$ weed $/ \mathrm{m}^{2}=0.0929$ weed $/ \mathrm{ft}^{2}$.

NS, ${ }^{*}, *$ Nonsignificant or significant at $P \leq 0.05$ or $P \leq 0.0001$, respectively. Means within the table followed by the same letter do not differ significantly according to Fisher's protected least significant difference test $(P \leq 0.05)$ 
CROP GROWTH REDUCTION. Only minor pumpkin plant growth reduction $(<10 \%)$ was observed during the early season, with no differences $(P>$ 0.05 ) observed between the two initial stale seedbed burndown treatments or between the second series of herbicide applications, which only compared the PRE application with no herbicide (Table 1). The POST clethodim application for the second series of herbicide treatments and the midseason paraquat application between rows were not made until the early-season data were collected.

Pumpkin plant growth reduction was influenced by herbicide treatment and application timing. Although greater amounts of growth reduction were observed during the late season compared with early season (Table 1 ), no differences $(P>0.05)$ were observed between glyphosate and paraquat as initial burndown applications. However, differences $(P \leq 0.05)$ were detected between all treatments evaluated for the second herbicide application during the late season, with $60 \%$ reduction observed in the no herbicide treatment compared with $36 \%$ and $16 \%$ in the PRE only and PRE and POST application, respectively. For the late-season evaluation, the midseason herbicide application of paraquat between rows resulted in less crop growth reduction compared with no treatment because of the increased grass and broadleaf weed control achieved with this application. For all herbicide application timings, the pumpkin plant growth reduction observed later in the growing season was due to insufficient weed control.

Weed Density. Herbicide application timing and treatment influenced weed density in NT pumpkins. Although the two stale seedbed burndown herbicide treatments did not differ $(P>0.05)$ for grass or broadleaf weed density, the paraquat application reduced horseweed weed density more than the glyphosate treatment (Table 1). For the second herbicide application, grass density was also much greater in the PRE only and no herbicide treatments compared with the PRE and POST treatment, which was expected as the POST clethodim treatment is used only for grass weed control. However, broadleaf weed and horseweed density was unaffected by PRE or PRE and POST herbicide treatments compared with no herbicide at this second herbicide application timing. The midseason herbicide application of paraquat between rows resulted in no reduction in grass weed density although this application resulted in less broadleaf and horseweed density compared with no application.

Pumpkin Yield. Herbicide application timing and treatment affected pumpkin yield under NT production practices. Although the initial stale seedbed burndown treatments did not differ $(P>0.05)$ for average pumpkin weight or diameter, the use of paraquat at this timing increased both pumpkin fruit number and weight per acre and fruit number per plant by $31 \%, 59 \%$, and $27 \%$, respectively, compared with glyphosate (Table 2).

Pumpkin yield differences $(P \leq$ $0.05)$ were also detected among treatments for the second herbicide application (Table 2). Although the PRE only treatment improved most pumpkin yield parameters compared with the no herbicide treatment, the PRE and POST application provided the highest yields. The PRE and POST herbicide application produced the highest pumpkin fruit numbers and weights per acre, and fruit numbers per plant, as well as the greatest average pumpkin fruit size based on both weight and diameter.

The midseason herbicide application of paraquat between rows improved all pumpkin yield parameters compared with no herbicide (Table 2). Pumpkin fruit numbers and weights per acre increased by $16 \%$ and $34 \%$, respectively, with a midseason paraquat application. Furthermore, pumpkin fruit weight and diameter, as well as fruit number per plant increased $15 \%, 7 \%$, and $18 \%$, respectively, when paraquat was used at this timing.

\section{Discussion}

Acceptable weed control is difficult to achieve in NT pumpkin production. For pumpkin growers who use NT, the use of herbicides, cover crops, and cover crop or previous crop residues play an important role in weed management. Russo et al. (2006) indicated that a base of standing, dead stubble is an important part of a NT system for pumpkins since this residue provides many benefits toward more sustainable production practices and does not compete for resources with developing pumpkin

Table 2. Effect of herbicides and application timings in no-tillage pumpkin production on jack-o-lantern pumpkin yield.

\begin{tabular}{|c|c|c|c|c|c|}
\hline \multirow[b]{2}{*}{ Main effect ${ }^{\mathrm{z}}$} & \multicolumn{5}{|c|}{ Pumpkin fruit ${ }^{y}$} \\
\hline & $(\text { no. } / \text { acre })^{\mathrm{x}}$ & $\begin{array}{c}\mathrm{Wt} \\
(\mathrm{lb} / \text { acre })^{\mathrm{x}}\end{array}$ & $\begin{array}{l}\operatorname{Avg} w t \\
(1 \mathrm{~b})^{x}\end{array}$ & $\begin{array}{c}\text { Avg diam } \\
\text { (inches) }^{x}\end{array}$ & (no./plant) \\
\hline \multicolumn{6}{|c|}{ Stale seedbed burndown } \\
\hline Glyphosate & 1,338 & 11,838 & 8.6 & 8.3 & 1.1 \\
\hline Paraquat & 1,756 & 18,831 & 10.4 & 8.9 & 1.4 \\
\hline Significance & * & * & NS & NS & * \\
\hline \multicolumn{6}{|c|}{ Preemergence (PRE) and postemergence (POST) applications } \\
\hline PRE only & $1,503 \mathrm{~b}$ & $14,448 \mathrm{~b}$ & $9.3 \mathrm{~b}$ & $8.6 \mathrm{~b}$ & $1.2 \mathrm{~b}$ \\
\hline PRE and POST & $1,746 \mathrm{a}$ & $20,040 \mathrm{a}$ & $11.2 \mathrm{a}$ & $9.4 \mathrm{a}$ & $1.4 \mathrm{a}$ \\
\hline None & $1.356 \mathrm{~b}$ & $10,943 \mathrm{c}$ & $7.9 \mathrm{c}$ & $7.9 \mathrm{c}$ & $1.1 \mathrm{~b}$ \\
\hline \multicolumn{6}{|c|}{ Between row paraquat application } \\
\hline Between rows & 1,646 & 17,341 & 10.1 & 8.9 & 1.3 \\
\hline None & 1,425 & 12,950 & 8.8 & 8.3 & 1.1 \\
\hline Significance & ** & $* * *$ & ** & ** & ** \\
\hline
\end{tabular}

${ }^{z}$ The stale seedbed burndown treatments consisted of glyphosate $(22 \mathrm{fl} \mathrm{oz} /$ acre $)$ or paraquat $(3 \mathrm{pt} / \mathrm{acre})+1 \% \mathrm{v} / \mathrm{v}$ crop oil concentrate (COC) applied $3 \mathrm{~d}$ before transplanting pumpkins. The preemergence (PRE) and postemergence (POST) applications were: 1) PRE only-s-metalochlor (1.33 pt/acre) + halosulfuron-methyl (0.5 oz/acre); 2) PRE and POST - s-metalochlor (1.33 pt/acre $)+$ halosulfuron-methyl $(0.5 \mathrm{oz} / \mathrm{acre})-\mathrm{PRE}$ and then clethodim $(8 \mathrm{fl} \mathrm{oz} /$ acre $)+1 \% \mathrm{v} / \mathrm{v}$ COC - POST; and 3$)$ no herbicide treatment. The PRE herbicides were applied to soil $\mathrm{l} \mathrm{d}$ before transplanting and the POST application of clethodim was made 4 weeks after transplanting. The midseason between row application was paraquat $(3 \mathrm{pt} / \mathrm{acre})+1 \% \mathrm{v} / \mathrm{v}$ COC directed POST between pumpkin rows at $\approx 50 \mathrm{~d}$ after transplanting or no treatment; $1 \mathrm{fl} \mathrm{oz} /$ acre $=0.0731 \mathrm{~L} \cdot \mathrm{ha}{ }^{-1}, 1 \mathrm{pt} / \mathrm{acre}=$ $1.1692 \mathrm{~L} \cdot \mathrm{ha}^{-1}, \mathrm{l} \mathrm{oz} /$ acre $=70.0532 \mathrm{~g} \cdot \mathrm{ha}^{-1}$.

yPumpkin fruit yields are based on two harvests of mature, orange-colored pumpkins on $\approx 10$ Sept. and 10 Oct. each year.

${ }^{\mathrm{x}} \mathrm{l}$ fruit $/ \mathrm{acre}=0.4047 \mathrm{fruit} / \mathrm{ha}, \mathrm{llb} / \mathrm{acre}=1.1209 \mathrm{~kg} \cdot \mathrm{ha}^{-1}, \mathrm{l} \mathrm{lb}=0.4536 \mathrm{~kg}, \mathrm{l}$ inch $=2.54 \mathrm{~cm}$

Ns, ${ }^{*}, * * * *$ Nonsignificant or significant at $P \leq 0.05, P \leq 0.01$, or $P \leq 0.0001$, respectively. Means within the table followed by the same letter do not differ significantly according to Fisher's protected least significant difference test $(P \leq 0.05)$. 
seedlings. Although weed control is improved with crop residues, such as wheat stubble and straw that were used in this study, the use of effective herbicides in combination with cover crop or crop residues integrated into NT planting systems are critical for pumpkin growers to enhance weed control (Maynard, 2008; Rapp et al., 2004; Walters and Young, 2010; Walters et al., 2008). However, the lack of effective herbicides available for pumpkin has hindered the adoption of NT pumpkin production systems (Walters, 2011).

Herbicide application and timing in NT pumpkin production systems are both important grower concerns to optimize weed control so that the highest possible pumpkin yields can be obtained. This study indicated that: 1) paraquat generally provided better broadleaf weed control than glyphosate (especially horseweed) for an initial stale seedbed burndown treatment, which lead to improved pumpkin yields, 2) the use of $s$-metolachlor + halosulfuron-methyl PRE and clethodim POST gave the best results for the second series of herbicide applications and lead to higher pumpkin yields compared with no treatment or only a PRE application, and 3) the midseason between row application of paraquat also improved weed control and provided higher pumpkin yields compared with no midseason treatment.

Chemical weed management practices that are often not used in NT pumpkin production (e.g., paraquat as a stale seedbed herbicide treatment or as a midseason shielded application between rows) have the potential to improve grass and broadleaf weed control, which will often lead to higher pumpkin yields. The use of stale seedbed weed management techniques is crucial to maximize yields of crops that have limited herbicide options (Johnson and Mullinix, 1998). Although pumpkin vegetation will provide some soil shading and weed suppression once vines form across the soil surface (Walters, 2011), the use of nonselective POST herbicide applications (e.g., paraquat) to row middles, before pumpkin vines spread across the soil surface, will improve weed control. This method of chemical weed control in NT is similar to a midseason cultivation in CT that removes weeds before vines cover the soil surface. Similar to Maynard (2008), this midseason nonselective shielded application provides additional weed control that contributes in maximizing pumpkin yield in a NT system. Thus, the judicious use of herbicides and their appropriate timing are important parts of an effective weed management program for NT pumpkin.

All application timings that were used in this study over the pumpkin growing season were important to maximize weed control in a NT system. The majority of NT pumpkin growers use glyphosate as the herbicide for a stale seedbed burndown treatment although paraquat may prove to be a better choice depending on the weeds that are present. Typically, most weed control obtained in NT pumpkin production is provided by a PRE application of various tankmixed herbicides for both grass and broadleaf weed control, with a POST grass herbicide, a POST application of halosulfuron-methyl, or both (for control of certain broadleaf weed species) applied 3 to 4 weeks later. Although most growers do not use a POST-directed application of a nonselective herbicide (such as paraquat) in NT systems before pumpkin plant vining, it appears that this application timing may be warranted to control weeds that have emerged later in the growing season to maximize pumpkin yield.

Herbicide application timing in NT pumpkin production plays an important role in optimizing weed control, which will lead to improvements in fruit yield. This study indicated that in addition to applying the limited PRE and POST herbicides available for weed control in pumpkin, the use of other alternative chemical weed management practices can provide valuable weed control in NT production systems. Although these practices should be considered by growers to obtain the highest possible pumpkin yields, it is also important to remember that the establishment of a dense, uniformly distributed mulch residue on the soil surface is also important to maximize weed control in NT systems (Morse, 1999).

\section{Literature cited}

Blevins, R.L., M.S. Smith, G.W. Thomas, and W.W. Frye. 1983. Influence of conservation tillage on soil properties. J. Soil Water Conserv. 38:301-304.

Brown, D. and J. Masiunas. 2002. Evaluation of herbicides for pumpkin (Cucurbita spp.). Weed Technol. 16:282-292.

Egel, D., R. Foster, E. Maynard, R. Weinzierl, M. Babadoost, H. Taber, R. Bauernfeind, T. Carey, M. Kennelly, B. Hutchison, and B. Barrett. 2008. Midwest vegetable production guide for commercial growers-2008. Univ. Illinois Ext. Bul. C1373-08.

Egel, D., R. Foster, E. Maynard, R. Weinzierl, M. Babadoost, H. Taber, R. Bauernfeind, T. Carey, M. Kennelly, B. Hutchison, and S. Gu. 2009. Midwest vegetable production guide for commercial growers-2009. Univ. Illinois Ext. Bul. C1373-09.

Galloway, B.H. and L.A. Weston. 1996. Influence of cover crop and herbicide treatment on weed control and yield in no-till sweet corn (Zea mays L.) and pumpkin (Cucurbita maxima Duch.). Weed Technol. 10:341-346.

Grey, T.L., D.C. Bridges, and D.S. NeSmith. 2000. Tolerance of cucurbits to the herbicides clomazone, ethalfluralin, and pendimethalin. I. Summer squash. HortScience 35:632-636.

Herman, R.J. 1979. Soil Survey of Jackson County, Illinois. Illinois Agr. Expt. Sta. Soil Rpt. 106.

Johnson, A.M. and G.D. Hoyt. 1999. Changes to the soil environment under conservation tillage. HortTechnology 9:380-393.

Johnson, W.C., III and B.G. Mullinix, Jr. 1998. Stale seedbed weed control in cucumber. Weed Sci. 46:698-702.

Kammler, K.J., S.A. Walters, and B.G. Young. 2008. Halosulfuron tank-mixtures and adjuvants for weed control in pumpkin production. HortScience 43:18231825 .

Maynard, E.T. 2008. Weed Control in No-till Pumpkins. Purdue Fruit and Vegetable Research Reports. Paper 7. 15 Nov. 2011. <http://docs.lib.purdue. edu $/$ cgi $/$ viewcontent .cgi? article $=1009 \&$ context $=$ fvtrials $>$.

Morse, R.D. 1999. No-till vegetable production-its time is now. HortTechnology 9:373-379.

Morse, R., T. Elkner, and S. Groff. 2001. No-till pumpkin production principles and practices. Pennsylvania Marketing and Research Program, Harrisburg, PA.

Rapp, H.S., R.R. Bellinder, H.C. Wien, and F.M. Vermeylen. 2004. Reduced tillage, rye residues, and herbicides influence 


\section{Research Reports}

weed suppression and yield of pumpkins. Weed Technol. 18:953-961.

Russo, V.M., B. Kindiger, and C.L. Webber, III. 2006. Pumpkin yield and weed populations following annual ryegrass. J. Sustain. Agr. 28:85-96.

Walters, S.A. 2011. Weed management systems for no-tillage vegetable production, p. 17-40. In: S. Soloneski and M. Larramendy (eds.). Herbicides: Theory and applications. InTech, Rijeka, Croatia.

Walters, S.A. and B.G. Young. 2010. Effect of herbicide and cover crop on weed control in no-tillage jack-o-lantern pumpkin production. Crop Protection 29:30-33.
Walters, S.A., B.G. Young, and R.F. Krausz. 2008. Influence of tillage, cover crop, and preemergence herbicides on weed control and pumpkin yield. Intl. J. Veg. Sci. 14:148-161. 